\title{
Hybrid Filament-wound Materials: Tensile Characteristics of (Aramide Fiber/Glass Fiber)-Epoxy Resins Composite and (Carbon Fibers/Glass Fiber)-Epoxy Resins Composites
}

\author{
Jovan Radulović ${ }^{1)}$
}

\begin{abstract}
In this paper a tensile characteristics of filament-wound glass fiber-aramid fiber/epoxy resins hybrid composites and glass fiber-two carbons fibers/epoxy resins hybrid composites are presented. Basic terms about hybride composite materials (origin, reasons for manufacturing, advantages, definitions, levels of hybridization, modes of classifications, types, categorization, and possible interactions between constituents) and used reinforcements and matrices are described. For a manufacturing of NOL rings four reinforcements (glass fiber, polyamide aromatic fiber and two carbon fibers) and two matrices (high- and moderate- temperature curing epoxy resin system) are used. Based on experimentally obtained results, it is concluded that hybride composite material consisting of carbon fiber T800 (67\% vol) and glass fiber GR600 (33\% vol) impregnated with epoxy resin system L20 has the highest both the tensile strength value and the specific tensile strength value. The two lowest values of both tensile strength and the specific tensile strength have hybrid material containing aramide fiber $\mathrm{K} 49(33 \%$ vol) and glass fiber GR600 (67\% vol) and epoxy resin system 0164 and hybrid NOL ring with wound carbon fiber T300 (33\% vol) and glass fiber GR600 (67\% vol) impregnated with the same epoxy resin system. This investigation pointed out that increasing the volume content of aramide fiberK49, carbon fiber T300 and carbon fiber T800 in appropriate hybrid composites with glass fiber GR600 increases both the tensile strength value and the specific tensile strength value and decrease the density value, no matter the used epoxy resin system.
\end{abstract}

Key words: hybride composites, glass fiber, aramide fiber, carbon fiber, epoxy resin system, NOL ring, tensile strength, density, specific tensile strength, filament winding technology.

\section{Introduction}

$\mathrm{E}^{\mathrm{s}}$ $\mathrm{ACH}$ tekst. of design stages requires decisions about material from which the product is to be made and the process for making it. The choice of material is dictated by the design. But sometimes it is the way around: the new product, or evolution of existing one, was made possible by new material, or precisely spoken, by material with new properties.

Material property is defined as a measuring value by which the shape or the measure of material capability to react to external influence, are characterized.

According to the nature of external influences on material, characteristics of material can be classified into three groups: 1.) mechanical characteristics, 2.) physical characteristics and 3.) chemical characteristics. Mechanical characteristics refer to material behavior under mechanical stress, i.e. under the influence of mechanical forces [1].

There are three types of static stresses too which materials can be subjected: 1.) tensile stress, 2.) compression stress and 3.) shear stress. Tensile stress tends to stretch the material, compression stress tends to squeeze it, and shear involves stress that tends to cause adjacent portions of material to slide against each other [2].

Composite materials are one of four basic engineering materials. These materials are consisting of reinforcing phase (reinforcement) and impregnating phase (matrix) [3].

Primary function of reinforcement is to carry load along the length of the fiber, provides strength and stiffness.
Primary function of matrix is to transfer stress between reinforcing fibers and to protect them from mechanical and environmental damage (elevated temperature, humidity, corrosion, etc) [4].

Three main impregnating phases for manufacturing of composite materials are polymeric matrix, metal matrix and ceramic matrix. Reinforcing phase can be either any of three mentioned materials (polymer, metal and ceramic) or some elements (carbon, boron) [2].

Generally speaking, it is considered that hybrids exist when two or more different materials are processed together (coextrusion, coinjection, reinforced polymer construction, etc.) [5].

There are hybrid reinforced polymer materials that have two or more fiber reinforcements embedded in the polymer matrix. They have evolved as a logical sequel to conventional single fiber reinforced polymer material. With growing understanding of the chemistry processes and a wider choice of components, manufactures are introducing hybrid resins (made of two or more polymer components). The most common hybrid is polyester/polyurethane two component system. The A component comprise isocyanate and additives and the B component is a low molecular weight unsaturated polyester resin with additives. The isocyanate reacts with a polyol to develop a very high molecular weight linear polymer, a monomer such is styrene reacts with unsaturated portion of polyol to add strength and stiffness, creating a cross-linked structure [6].

\footnotetext{
1) Military Technical Institute (VTI), Ratka Resanovića 1, 11132 Belgrade, SERBIA

Correspondence to: Jovan Radulović, e-mail: jovan.r.radulovic@gmail.com
} 
Some hybrid materials represent attempts to reduce the cost of the expensive composites containing reinforcements like carbon fibers by incorporating a proportion of cheaper, lowerquality fibers like glass without too seriously reducing the mechanical characteristics of the original composite materials. Of equal importance is the reverse principle, and that is stiffening of structure with glass fibers with an adequate quantity of carbon or aromatic polyamide fiber, without enlarging a cost of starting composite material to a higher extent. The important aspect of using hybrid composite is understanding the way that enables better characteristics of this kind of material which allows even closer tailoring of composite material properties to suit specific requirements that cannot be achieved by using single-fiber types of composite materials [7].

Two advantages of hybrid composites are: 1) better overall property combinations, and 2) failures not as catastrophic as with single-fiber composite.

The concept of hybrid material is a simple extension of the composite principle of combining two or more materials to optimize their values, permitting the exploitation of their better qualities, while simultaneously mitigating the effects of their less desirable properties. Besides the choice of fibers for hybridization, there is, also, an important question of arrangement or dispersion of the separate components. The coarsest structural level is skin-core structure, where skin must sustain external forces and protect the core. Perhaps the easiest and cheapest structural level of hybridization is ply-toply. It allows more flexibility in tailoring and composition than tow-to-tow level of hybridization. In this third level prefabricated hybrid reinforcement, woven or nonwoven, of given composition are used and provide more homogeneous dispersion of the reinforcement components. The finest level of hybridization is that in which components of fibers are intimately mixed, ideally in random fashion, but almost exclusively with short fibers. The mentioned four level of hybridization is presented in Fig.1 [8].

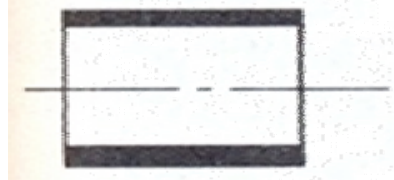

a

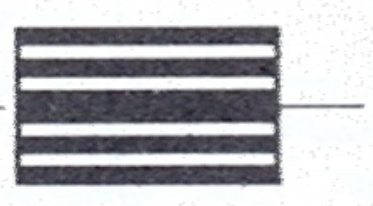

b

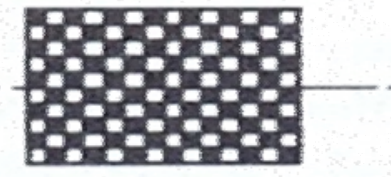

c

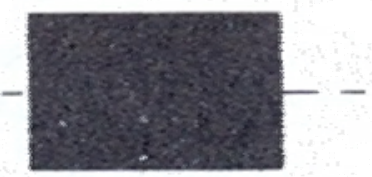

d

Figure 1. Schematic illustration of different level of hybridization [8]

Maybe the oldest but still very valuable classification of hybrid composite stated that there are four basic types of these materials:

1. Interplay hybrids consisting of plies of two or more different unidirectional composite stacked in a specific sequence, skin - core composites belong to this type,

2. Intraply hibrids consist of two or more different fibers mixed in the same ply,

3. Interply/intraply hybrids consisting of plies interplay and intraply stacked in a specific sequence and

4. Super hybrids consisting of polymeric (mostly resin) matrix composite plies and metal matrix composite plies stacked in a specific sequence [9].

Hybrids have unique features that can be used to meet diverse and unusually design requirements in a more costeffective way than either advanced or widely used composites. Some of specific advantages of hybrids over conventional composites are balanced strength and stiffness, balanced bending and membrane mechanical properties, balanced thermal distortion stability, reduced weight and/or cost, improved fatigue resistance, reduced notch resistivity, improved fracture toughness and/or crack arresting properties and improved impact resistance [9,10].

In a narrow sense, hybrid is a term applied to advanced composites and refers to the use of various combinations of continuous reinforcements either in thermoreactive or thermoplastic matrices [5].

A hybrid material refers to any of a class of materials in which organic and inorganic components are intimately mixed. Many natural materials consist of inorganic and organic building blocks. In most cases the inorganic part provides mechanical strength and an overall structure to the natural objects while the organic part delivers bonding between the inorganic building blocks and/or the soft tissue. Typical examples of such materials are bone, or nacre. It is considered that the first hybrid materials were the paints made from inorganic and organic components that were used few thousands of years ago.

Hybrid materials can be classified based on the possible interactions connecting the inorganic and organic species. Class I hybrid materials do not have any covalent or ionic bonds and show weak interactions between the two phases, such as Van der Waals, hydrogen bonding or weak electrostatic interactions. Class II hybrid materials are those that show strong chemical interactions between the components such as covalent bonds [11].

There are various types of hybrid composites such as hybrids between synthetic-synthetic fibers, synthetic-natural fibers, and natural-natural fibers. The synthetic fibers normally used for hybrid composites are glass, carbon and aramide fibers [12].

Ashby and Bréchet defined hybrid materials as, "a combination of two or more materials in a predetermined geometry and scale, optimally serving a specific engineering purpose" [13].

Summerscales defined production of hybrid composite materials as incorporation of two or more fibers within a single matrix or it may be two resin systems, e.g. an interpenetrating network [14].

Yamada et al. defined hybrid materials as mixtures of two or more materials with new properties created by new electron orbitals formed between each material, such as covalent bond between polymer and silanol molecular in inorganic/organic hybrids. They proposed this definition of "hybrid" materials by expanding the concept of inorganic/organic hybrid materials [15].

Gómez-Romero and Sanchez defined hybrid materials as organic-inorganic hybrid materials or inorganic-biomaterials [16].

Niizeki described hybrid materials as involving two or more kinds of chemical-bonds created by "hybridizing" two or more monolithic materials, and as a result hybrid material has a superior performance and/or new functions in comparison with their component monolithic counterparts [17].

Classification of hybrid composite materials proposed by Jawaid and others is presented in Fig.2 [18]. 


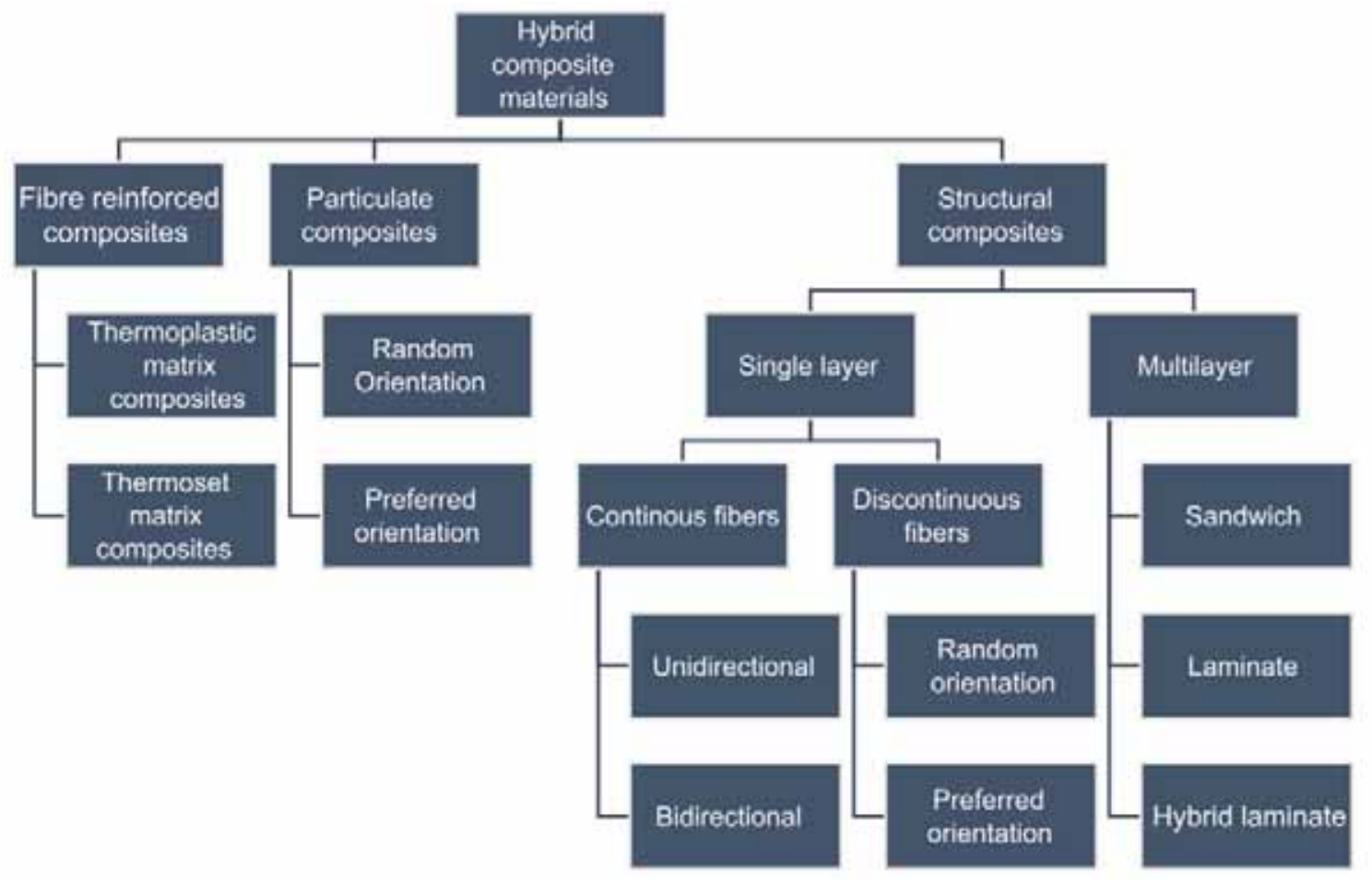

Figure 2. Classification of hybrid composite materials [18]

Perov and Khoroshilova proposed five main types of polymeric hybrid composite materials (in further text: PHCM):

5. Averaged. Fibers of different types in such a PHCM are mixed in the whole mass of the material. No sections with macro concentrations of any type of fiber are available.

6. Intralaminar. Fibers of different types in each layer of PHCM are regularly alternated. Referred to this type of PHCM are materials based on reinforcing hybrid fabrics.

7. Interlaminar. Each layer of PHCM consists of one type of fiber. As a whole, the PHCM is made up of layers alternating in a definite order from fibers of different types (e.g., part from carbon plastic or organic fiberreinforced plastic)

8. Separate reinforcing elements.

9. Super hybrids. Layers of composites based on organic polymer and metal matrix and sheets of metal foil are laid in a definite pattern [19].

Makishima defined hybrid materials as mixtures of two or more materials with newly-formed chemical-bonds. He proposed next categorization of hybrid materials:

1. Composites: Mixture of materials consisting of matrix and micron-level dispersion.

2. Nanocomposites: Sub-micron level mixture of similar kinds of materials.

3. Hybrids: Sub-micron level mixture of different kinds of materials.

4. Nanohybrids: Atomic or molecular level mixture of different materials with chemical-bonds between their different materials [20].

In this paper a mechanical property, concretely tensile properties of filament-wound glass fiber-moderate strength carbon fiber/epoxy resin hybrid composites, glass fiberaramid fiber/epoxy resin hybrid composites and glass fiberhigh strength carbon fiber/epoxy resin hybrid composites will be discussed.
Zhang et al. conducted research on the tensile, flexural and compressive responses of woven hybrid composites by using different arrangement and glass/carbon ratio. The results showed that the ratios of glass/carbon FRP composites in 50:50 have improved the tensile, flexural and compressive strength effectively [21].

Raghavalu Thirumalai and others used epoxy resin, carbon/glass hybrid fabric, carbon fiber and glass fiber rovings and produced UD hybrid composites by laminating and by filament winding techniques. They concluded that fiber arrangement and its parameters have significant influence on the obtained results and pointed out fact that filament- wound specimens have a better tensile and compression properties compared to fabric-based composites [22].

Irina et al. produced hybrid specimens with three orientation schemes of carbon and E-glass fibers ( $[\mathrm{CWW}]_{6}$, $[\mathrm{BC}]_{6}$, and $[\mathrm{CBBC}]_{3}$ ), where $\mathrm{C}, \mathrm{W}$ and $\mathrm{B}$ represent carbon fiber, E-glass plain woven and E-glass bi-axial, respectively, and 6 and 3 are a number of layers. They concluded that mechanical performance for $[\mathrm{CWW}]_{6}$ hybrid composites is better than that of the others hybrid combination in terms of tensile and flexural mechanical performance. Although the replacement a portion of carbon will increase the overall costing of fiber reinforced polymer composite, however it is still worthy to supplant the low cost of pure FRP composites. Hybrid composites with lighter weight and higher strength are one of the keys to moderate the shortage of petrol fuel as well as reduce the environmental burden of automotive vehicles or aerospace structural [23].

Lokman and others presented experimentally obtained mechanical properties and machinability characteristic of filament wound hybrid composite pipes with various stacking sequences of glass and carbon fibers (Glass-Carbon-Glass (GCG), Carbon-Glass-Glass (CGG), and Glass-Glass-Carbon (GGC)). In order to determine the mechanical properties of the pipes, hardness test (Shore D), ring tensile test (ASTM D2290), and burst test (ASTM D1599) were carried out. Machinability tests were performed at various feed rates $(50,150,250$ and 350 $\mathrm{mm} / \mathrm{min}$ ) and spindle speeds (796, 1592, 2388 and $3184 \mathrm{rpm})$. 
The results showed that stacking of the carbon layer between two glass layers (GCG) presented better performance in terms of mechanical properties and machinability characteristic. The maximum ring tensile stress of GCG specimen is $27 \%$ and $19 \%$ higher than those of GGC and CGG specimens, respectively. On the other hand, the lowest thrust forces were measured during the drilling of GCG specimen while the GGC represented highest values [24].

Zuraida and others carried out an experimental and finite element analyses for hybrid and non-hybrid glass and carbon/epoxy composite tubes subjected to quasi static lateral indentation loading. Four types of composite tubes, each of four layers and approximately 1,6 $\mathrm{mm}$ wall thickness were fabricated by filament winding process. Tube length and inner diameter are, respectively, 350 and $100 \mathrm{~mm}$. Fiber orientation angles of $+55^{\circ},-55^{\circ},+55^{\circ},-55^{\circ}$ angle ply were considered for all the fabricated tubes. Hemispherical steel indenter of 50 $\mathrm{mm}$ diameter was used as an indenter. A comparison was done for the tested composite tubes between the finite element and the experimental results. The results obtained from this study show that carbon/epoxy tubes resists higher load with less deformation than the glass and hybrid glass-carbon tubes. Also, the results show that the stacking sequence of hybrid composite tubes can be used to improve their strength and performance. For hybrid types tested, tubes with the external layer of carbon show higher strength than those of internal carbon fiber layers. It has been found that the loaddisplacement difference between the experimental and finite element results fell in the range of $1,2-18 \%$, while the strain results fell in the range of $2-21 \%$ [25].

In this study Özbek investigated the effects of fiber hybridization on mechanical properties of composite pipes fabricated by filament winding technique. Axial compression behaviors and stiffness characteristics of the samples were determined according to ASTM D695 and ASTM D2412, respectively. In addition, the samples were separately compressed in axial and lateral directions and the crushing behaviors were determined in these directions. Finally, ignition loss tests were carried out in accordance with ASTM D2584 to determine the fiber contents of the samples. The quasi-static compression performance of hybrid samples was found to be marginally different in axial and radial directions such as; inclusion of carbon fiber improved compression strength in the axial direction while leading decrease of pipe stiffness in the radial direction. Crushing procedure of hybrid composite pipes were seen as more stable and regular compared to non-hybrid ones [26].

Tariq and others investigated the effect of hybrid reinforcement on the performance of filament wound hollow shaft. The hybrid shafts are composed of hybrid filaments including a combination of carbon, glass and aramid fibers. The shafts were manufactured using filament winding processing technique employing suitable matrix and reinforcement systems and were tested for torsional characteristics, hardness, density and chemical reactivity. The results showed that carbon fiber reinforcement shows the best results in terms of torsional characteristics. In terms of chemical reactivity, carbon-glass hybrid reinforcement exhibited minimum degradation. Furthermore, it was also found that hybrid reinforcements containing carbon-aramid fibers showed better results in terms of density and surface hardness [27].

High performance composite materials are nowadays widely employed in many advanced engineering fields due to overall set of characteristics. Primarily mechanical characteristics of these materials make them attractive for structural applications where high strength-to-weight and stiffness-to-weight ratios are required. High performance composite materials satisfy requirements for high specific tensile strength and specific stiffness, low coefficient of thermal expansion, good fatigue resistance, high dumping properties, dimensional stability during operational lifetime, and offer minimum materials solution for these structures [28].

Different technologies can be used for a manufacturing of a fiber reinforced composite parts. The filament winding technology (vikling in Norway, filaman sargi in Turkey, wickelferfahren in Germany, филаментная намотка in Russia, etc.) is used in this investigation.

The art of mummification that flourished in Egypt during 2500 B.C. exemplifies one of the first filament winding process. Suitably treated dead bodies were wrapped in tapes of linen and then impregnated with a natural resin to produce, ultimately a rigid cocoon [29].

First official recorded use of filament winding technology was for lightweight reinforced plastic hoop for Manhattan project in 1945 (which later become the basis for Naval Ordonance Laboratory - NOL - rings used for tension tests) [6].

Essential property and advantage of filament winding technology over other composite materials production procedures is a fact that reinforcing agent, i.e. continuous fiber is placed in the direction in which the stress during exploitation of filament wound part is expected to occur [30].

Filament winding technology consists of following important processes:

- unwinding of continuous fiber (roving) from appropriate devices at a defined tension force,

- passing of roving through a bath with resin system and, at the same time, a basic impregnation of fibers by resin occurs,

- passing of resin impregnated fibers through a system of "combs" and "rings" during which an additional impregnation of fibers by resin occurs and an excess of resin from the roving band is removed,

- winding of a specified number of layers with resin impregnated band roving on an appropriate mandrel under defined winding angles,

- curing of the wound structure at ambient, moderate and high temperature, depending of the applied resin system,

- removing the cured filament-wound part from the mandrel,

- machining of the removed composite part (if necessary) and

- obtaining a finish filament-wound product [31].

\section{Experimental part}

For a manufacturing of NOL rings four reinforcement agents and two impregnated agents are used. Reinforcement agents are glass roving trade mark Glass Roving 600, polyamide aromatic fiber trade mark KEVLAR K49, carbon fiber trade mark Torayca T300 and carbon fiber trade mark Torayca T800. Impregnated agents are epoxy resin system consisting of epoxy resin trade mark Rutapox 0164, hardener trade mark Haerter HX and fastener trade mark BDMA and epoxy resin system containing epoxy resin trade mark EPIKOTE L20 and hardener trade mark EPICURE Curing Agent 960.

Glass roving trade mark Glass Roving 600 (in further text: glass roving GR600), 1160 tex, monofilament diameter $13 \times 10^{-6} \mathrm{~m}$, belongs to calcium alumino borsilicate glass product with low alkali content. Composites reinforced with roving made of this kind of glass (so called E-glass) possess good tensile strength, good compressive strength and stiffness, corrosion resistance, low cost and very good 
electrical properties. Glass roving GR600 is a product of ETEX Company, Serbia.

Polyamide aromatic fiber trade mark KEVLAR K49, 5070 dtex, monofilament diameter $11,9 \times 10^{-6} \mathrm{~m}$, is poly (p-phenylene terephthalamide).Polyamide aromatic (aramide) fiber KEVLAR K49 (in further text: aramide roving K49) is characterized by high tensile strength and modulus, low density, excellent resistance to impact, abrasion, noise and vibrations and good ability to limit crack propagation, but has a relatively low compression properties. Aramide roving K49 is produced by Du Pont de Nemorous Company, United States of America.

Carbon fiber trade mark Torayca T300-6000 (in further text: carbon roving T300), 3960 dtex, monofilament diameter $7 \times 10^{-6} \mathrm{~m}$, is moderate strength, standard modulus fiber used for production of composite with high quality, consistency, reliability and balanced characteristics.

Carbon fiber trade mark Torayca T800-12000 (in further text: carbon roving T800), $4550 \mathrm{dtex}$, monofilament diameter $7 \times 10^{-6} \mathrm{~m}$, is high strength, intermediate modulus fiber used for production of composite materials with high level and balanced characteristics.

Carbon roving T300 and carbon roving T800 are products of Toray Industries Company, Japan.

For the impregnation of mentioned glass, aramide and carbons fibers and production of the NOL rings by filament winding technology, two epoxy resin systems are used.

One epoxy resin system is consisting of epoxy resin trade mark Rutapox 0164, hardener trade mark Haerter HX and fastener trade mark BDMA. Epoxy resin trade mark Rutapox 0164 is liquid, low viscosity, unmodified bisphenol A-based resin. This epoxy resin is used for production of adhesive, lacquers, laminate, etc. Hardener trade mark Haerter HX is liquid, low viscosity cycloaliphatic dicarbon acid anhydride. Owing to low viscosity and appropriate reactivity is suitable for impregnation of fibers and other reinforcements and production of laminate composite, in adequate resin system. Fastener trade mark BDMA is tertiary, modified amine (benzyl dimethylamine) of very low viscosity.

Epoxy resin Rutapox/hardener Haerter HX/fastener BDMA (in further text: epoxy resin system 0164) is used for production of fiber reinforced composite products with excellent mechanical and electrical characteristics. Epoxy resin system 0164 is high-temperature curing system.

Epoxy resin Rutapox 0164, hardener HX and fastener BDMA are products of Bakelite Kunststoffe, Germany.

Epoxy resin trade mark EPIKOTE L20 and hardener trade mark EPICURE Curing Agent 960 are constituents of another epoxy resin system used in this investigation. Epoxy resin trade mark EPIKOTE L20 is low viscosity, free of solvents and fillers. Hardener trade mark EPICURE 960 is aminebased curing agent with low viscosity.

Epoxy resin system EPIKOTE L20 / EPICURE 960 (in further text: epoxy resin system L20) is a low viscosity laminating mixture with outstanding wetting and adhesion characteristics on glass, carbon and aramide fibers. Epoxy resin system L20 is a moderate temperature curing system and is used for a production of composites with highest static and dynamic strength.

Epoxy resin EPIKOTE L20 and hardener EPICURE 960 are products of Hexion Inc. Company, United States of America.

NOL rings, tested in the experiments, were prepared by filament winding of mentioned reinforcements impregnated by defined epoxy resin systems using the PLASTEX type PLA 500 machine (made by machine manufacturer PLASTEX-MANUHRINE, France). The NOL rings were wound on a highly polished steel cylindrical mandrel whose external diameter is $146 \mathrm{~mm}$, which provide that internal diameter of NOL rings is, also, $146 \mathrm{~mm}$.

Band of glass roving GR600 (consisting of four single roving) is wound on mandrel under the tension force $60 \mathrm{~N}$.

Aramide roving $\mathrm{K} 49$ is dried at temperature $105^{\circ} \mathrm{C}$ in a heating chamber with ventilation for a period of $2 \mathrm{~h}$, before the winding. Band of aramide roving K49 (consisting of four single roving) is wound on mandrel under the tension force $20 \mathrm{~N}$.

Band of carbon roving T 300 (consisting of four single roving) is wound on mandrel under the tension force $20 \mathrm{~N}$.

Band of carbon roving T 800 (consisting of two single roving) is wound on mandrel under the tension force $40 \mathrm{~N}$.

Filament-wound NOL rings impregnated with epoxy resin system 0164 cured at temperature $110^{\circ} \mathrm{C}$ in tunnel heating chamber with rotating mandrel for a period of $2 \mathrm{~h}$ (first stage) and, after that, at temperature $130^{\circ} \mathrm{C}$ in heating chamber without rotating mandrel and ventilating for a period of $4 \mathrm{~h}$ (second stage).

Filament-wound NOL rings impregnated with epoxy resin system L20 cured at temperature $70^{\circ} \mathrm{C}$ in tunnel heating chamber with rotating mandrel for a period of $15 \mathrm{~h}$.

Six types of hybrid NOL rings are produced by filament winding technology using glass roving GR600, aramide roving K49, carbon fiber T300, carbon fiber T800, epoxy resin system 0164 and epoxy resin system L20:

1. First type is consisting of glass roving GR600 and aramide roving K49 impregnated with epoxy resin system 0164,

2. Second type is consisting of glass roving GR600 and aramide roving K49 impregnated with epoxy resin system L20,

3. Third type is consisting of glass roving GR600 and carbon roving T300 impregnated with epoxy resin system 0164 ,

4. Fourth type is consisting of glass roving GR600 and carbon roving T300 impregnated with epoxy resin system L20,

5. Fifth type is consisting of glass roving GR600 and carbon roving T800 impregnated with epoxy resin system 0164 and

6. Sixth type is consisting of glass roving GR600 and carbon roving T800 impregnated with epoxy resin system L20.

Each of the six hybrid NOL rings type has five subtypes in which a relation of glass roving GR 600 and used appropriate roving (in volume percent) is changed from one hundred percent of glass roving (first subtype) to one hundred percent of another used roving (fifth subtype).

Hybrid NOL ring consisting of aramide roving K49 and glass roving GR600 impregnated with epoxy resin system 0164 , for the purpose of this paper, is marked as (K49/GR600+K49)-0164. Using this way of designation, other hybrid NOL rings have marks (K49/GR600 + K49) - L20, (T300/GR600 + T300) - 0164, (T300/GR600 + T300) - L20, (T800/GR600 + T800) - 0164 and (T800/GR600 + T800) - L20.

Experimental data for hybrid NOL rings mark $($ K49/GR600 + K49) - 0164 are shown in Table 1. Designations of used fibers, thickness of layers wound with appropriate fibers, volume contents of layers wound with appropriate rovings in overall volume of the rings, tensile strength data (single values and arithmetic mean values with standard deviations), density data (single values and arithmetic mean values with standard deviations) and specific tensile strength data (single values and arithmetic mean values with standard deviations) are presented in this Table $[32,33]$ 
Table 1. Experimental data for hybrid NOL rings mark (K49/GR600+K49)-0164

\begin{tabular}{|c|c|c|c|c|c|c|c|c|}
\hline \multirow{2}{*}{$\begin{array}{c}\text { Fiber } \\
\text { designation }\end{array}$} & \multirow{2}{*}{$\begin{array}{l}\text { Layers } \\
\text { thickness } \\
(\mathrm{mm}) \\
\end{array}$} & \multirow{2}{*}{$\begin{array}{c}\text { Volume } \\
\text { content } \\
(\%)\end{array}$} & \multicolumn{2}{|c|}{ Tensile strength (MPa) } & \multicolumn{2}{|c|}{ Density $\left(\mathrm{g} / \mathrm{cm}^{3}\right)$} & \multicolumn{2}{|c|}{ Specific tensile strength $\left(\mathrm{kPa} \mathrm{m}^{3} / \mathrm{kg}\right)$} \\
\hline & & & $\mathrm{X}_{\mathrm{i}}$ & $(\bar{X} \pm \sigma)$ & $\mathrm{X}_{\mathrm{i}}$ & $(\bar{X} \pm \sigma)$ & $\mathrm{X}_{\mathrm{i}}$ & $(\bar{X} \pm \sigma)$ \\
\hline $\begin{array}{c}\text { K49 } \\
\text { GR600 }\end{array}$ & $\begin{array}{c}6,3 \\
0\end{array}$ & $\begin{array}{c}100 \\
0\end{array}$ & $\begin{array}{l}1040,2 ; 1190,1 \\
1210,4 ; 1240,3 \\
1070,1 ; 1026,4 \\
1055,5 ; 1000,2\end{array}$ & $\begin{array}{c}1104,2 \\
\pm \\
93,9\end{array}$ & $\begin{array}{l}1,41 ; 1,39 \\
1,38 ; 1,40 \\
1,35 ; 1,36 \\
1,32 ; 1,38 \\
\end{array}$ & $\begin{array}{l}1,38 \\
\pm \\
0,02\end{array}$ & $\begin{array}{l}737,75 ; 856,19 \\
877,10 ; 885,93 \\
792,66 ; 754,71 \\
799,62 ; 724,78 \\
\end{array}$ & $\begin{array}{c}803,6 \\
\pm \\
63,3\end{array}$ \\
\hline $\begin{array}{c}\text { K49 } \\
\text { GR600 }\end{array}$ & $\begin{array}{l}4,2 \\
2,1\end{array}$ & $\begin{array}{l}67 \\
33\end{array}$ & $\begin{array}{c}1002,2 ; 1057,1 \\
957,6 ; 954,3 \\
1030,6 ; 923,3 \\
1018,3 ; 959,0 \\
\end{array}$ & $\begin{array}{c}987,8 \\
\pm \\
45,9\end{array}$ & $\begin{array}{l}1,48 ; 1,56 \\
1,56 ; 1,57 \\
1,56 ; 1,49 \\
1,57 ; 1,54 \\
\end{array}$ & $\begin{array}{l}1,54 \\
\pm \\
0,03\end{array}$ & $\begin{array}{l}690,67 ; 677,63 \\
613,85 ; 607,83 \\
660,64 ; 619,66 \\
648,60 ; 622,73 \\
\end{array}$ & $\begin{array}{c}642,8 \\
\pm \\
31,3\end{array}$ \\
\hline $\begin{array}{c}\text { K49 } \\
\text { GR600 }\end{array}$ & $\begin{array}{l}3,15 \\
3,15\end{array}$ & $\begin{array}{l}50 \\
50\end{array}$ & $\begin{array}{l}920,1 ; 972,1 \\
970,9 ; 896,1 \\
840,4 ; 940,9 \\
905,3 ; 873,8 \\
\end{array}$ & $\begin{array}{c}914,9 \\
\pm \\
45,9\end{array}$ & $\begin{array}{l}1,67 ; 1,72 \\
1,68 ; 1,71 \\
1,68 ; 1,66 \\
1,67 ; 1,68 \\
\end{array}$ & $\begin{array}{l}1,68 \\
\pm \\
0,02\end{array}$ & $\begin{array}{l}550,58 ; 565,17 \\
577,92 ; 524,03 \\
500,24 ; 566,81 \\
542,10 ; 520,12\end{array}$ & $\begin{array}{c}543,4 \\
\pm \\
26,9\end{array}$ \\
\hline $\begin{array}{c}\text { K49 } \\
\text { GR600 }\end{array}$ & $\begin{array}{l}2,1 \\
4,2\end{array}$ & $\begin{array}{l}33 \\
67\end{array}$ & $\begin{array}{l}929,0 ; 874,5 \\
851,6 ; 855,3 \\
886,3 ; 916,1 \\
880,7 ; 824,0 \\
\end{array}$ & $\begin{array}{c}877,2 \\
\pm \\
34,4\end{array}$ & $\begin{array}{l}1,83 ; 1,88 \\
1,85 ; 1,85 \\
1,81 ; 1,86 \\
1,85 ; 1,83 \\
\end{array}$ & $\begin{array}{l}1,85 \\
\pm \\
0,02\end{array}$ & $\begin{array}{l}507,65 ; 465,16 \\
460,32 ; 462,32 \\
489,67 ; 492,52 \\
476,06 ; 450,27 \\
\end{array}$ & $\begin{array}{l}475,5 \\
\pm \\
19,5\end{array}$ \\
\hline
\end{tabular}

Table 2. Experimental data for hybrid NOL rings mark (K49/GR600+K49)-L20

\begin{tabular}{|c|c|c|c|c|c|c|c|c|}
\hline \multirow{2}{*}{$\begin{array}{c}\text { Fiber } \\
\text { designation }\end{array}$} & \multirow{2}{*}{$\begin{array}{l}\text { Layers } \\
\text { thickness } \\
(\mathrm{mm})\end{array}$} & \multirow{2}{*}{$\begin{array}{c}\text { Volume } \\
\text { content } \\
(\%)\end{array}$} & \multicolumn{2}{|c|}{ Tensile strength (MPa) } & \multicolumn{2}{|c|}{ Density $\left(\mathrm{g} / \mathrm{cm}^{3}\right)$} & \multicolumn{2}{|c|}{ Specific tensile strength $\left(\mathrm{kPa} \mathrm{m}^{3} / \mathrm{kg}\right)$} \\
\hline & & & $\mathrm{X}_{\mathrm{i}}$ & $(\bar{X} \pm \sigma)$ & $\mathrm{X}_{\mathrm{i}}$ & $(\bar{X} \pm \sigma)$ & $\mathrm{X}_{\mathrm{i}}$ & $(\bar{X} \pm \sigma)$ \\
\hline $\begin{array}{c}\text { K49 } \\
\text { GR600 }\end{array}$ & $\begin{array}{c}6,3 \\
0\end{array}$ & $\begin{array}{c}100 \\
0\end{array}$ & $\begin{array}{l}1170,2 ; 1223,3 \\
1220,6 ; 1164,2 \\
1090,7 ; 1190,9 \\
1156,1 ; 1126,9 \\
\end{array}$ & $\begin{array}{c}1167,4 \\
\pm \\
45,4\end{array}$ & $\begin{array}{l}1,38 ; 1,37 \\
1,37 ; 1,41 \\
1,34 ; 1,30 \\
1,34 ; 1,38 \\
\end{array}$ & $\begin{array}{l}1,36 \\
\pm \\
0,03\end{array}$ & $\begin{array}{l}847,97 ; 892,92 \\
890,95 ; 825,67 \\
813,95 ; 916,07 \\
862,76 ; 814,42 \\
\end{array}$ & $\begin{array}{c}858,1 \\
\pm \\
39,1\end{array}$ \\
\hline $\begin{array}{c}\text { K49 } \\
\text { GR600 }\end{array}$ & $\begin{array}{l}4,2 \\
2,1\end{array}$ & $\begin{array}{l}67 \\
33\end{array}$ & $\begin{array}{r}971,4 ; 976,2 \\
1156,3 ; 994,7 \\
1042,2 ; 1165,6 \\
967,0 ; 1026,3 \\
\end{array}$ & $\begin{array}{c}1037,4 \\
\pm \\
80,7\end{array}$ & $\begin{array}{l}1,59 ; 1,51 \\
1,51 ; 1,51 \\
1,52 ; 1,57 \\
1,52 ; 1,53\end{array}$ & $\begin{array}{l}1,53 \\
\pm \\
0,03\end{array}$ & $\begin{array}{l}610,94 ; 646,49 \\
765,76 ; 658,74 \\
685,66 ; 742,42 \\
636,18 ; 670,78 \\
\end{array}$ & $\begin{array}{c}677,1 \\
\pm \\
52,9\end{array}$ \\
\hline $\begin{array}{c}\text { K49 } \\
\text { GR600 }\end{array}$ & $\begin{array}{l}3,15 \\
3,15\end{array}$ & $\begin{array}{l}50 \\
50\end{array}$ & $\begin{array}{c}933.4 ; 1007,0 \\
917,2 ; 916,31023,9 ; \\
944,0 \\
979,4 ; 918,0\end{array}$ & $\begin{array}{c}954,9 \\
\pm \\
43,0\end{array}$ & $\begin{array}{l}1,68 ; 1,67 \\
1,67 ; 1,72 \\
1,64 ; 1,59 \\
1,64 ; 1,68\end{array}$ & $\begin{array}{l}1,66 \\
\pm \\
0,04\end{array}$ & $\begin{array}{l}555,59 ; 602,99 \\
549,22 ; 532,73 \\
624,32 ; 593,71 \\
597,19 ; 546,43 \\
\end{array}$ & $\begin{array}{c}575,2 \\
\pm \\
33,2\end{array}$ \\
\hline $\begin{array}{c}\text { K49 } \\
\text { GR600 }\end{array}$ & $\begin{array}{l}2,1 \\
4,2\end{array}$ & $\begin{array}{l}33 \\
67\end{array}$ & $\begin{array}{rr}841,1 ; 845,1 \\
1027,3 ; 865,1 \\
913,2 ; 1038,6 \\
838,5 ; 896,3\end{array}$ & $\begin{array}{c}908,2 \\
\pm \\
81,5\end{array}$ & $\begin{array}{l}1,80 ; 1,84 \\
1,80 ; 1,75 \\
1,80 ; 1,80 \\
1,83 ; 1,77\end{array}$ & $\begin{array}{l}1,80 \\
\pm \\
0,02\end{array}$ & $\begin{array}{l}467,28 ; 459,29 \\
570,72 ; 494,34 \\
507,33 ; 577,00 \\
458,19 ; 506,38\end{array}$ & $\begin{array}{c}505,0 \\
\pm \\
46,8\end{array}$ \\
\hline
\end{tabular}

Table 2 contains experimental data for hybrid NOL rings mark (K49/GR600+K49)-L20.

Fiber designations, layers thickness, volume contents, tensile strength data (single values and arithmetic mean values with standard deviations), density data (single values and arithmetic mean values with standard deviations) and specific tensile strength data (single values and arithmetic mean values with standard deviations) for hybrid NOL rings mark (T300/GR600+T300)-0164 are presented in Table 3.

Table 3. Experimental data for hybrid NOL rings mark (T300/GR600+T300)-0164

\begin{tabular}{|c|c|c|c|c|c|c|c|c|}
\hline \multirow{2}{*}{$\begin{array}{c}\text { Fiber } \\
\text { designation }\end{array}$} & \multirow{2}{*}{$\begin{array}{l}\text { Layers } \\
\text { thickness } \\
(\mathrm{mm})\end{array}$} & \multirow{2}{*}{$\begin{array}{c}\text { Volume } \\
\text { content } \\
(\%)\end{array}$} & \multicolumn{2}{|c|}{ Tensile strength $(\mathrm{MPa})$} & \multicolumn{2}{|c|}{ Density $\left(\mathrm{g} / \mathrm{cm}^{3}\right)$} & \multicolumn{2}{|c|}{ Specific tensile strength $\left(\mathrm{kPa} \mathrm{m}^{3} / \mathrm{kg}\right)$} \\
\hline & & & $\mathrm{X}_{\mathrm{i}}$ & $(\bar{X} \pm \sigma)$ & $\mathrm{X}_{\mathrm{i}}$ & $(\bar{X} \pm \sigma)$ & $\mathrm{X}_{\mathrm{i}}$ & $(\bar{X} \pm \sigma)$ \\
\hline $\begin{array}{c}\text { T300 } \\
\text { GR600 }\end{array}$ & $\begin{array}{c}6,3 \\
0\end{array}$ & $\begin{array}{c}100 \\
0\end{array}$ & $\begin{array}{l}1230,1 ; 1265,8 \\
1298,2 ; 1144,5 \\
1129,6 ; 1265,7 \\
1040,0 ; 1201,1\end{array}$ & $\begin{array}{c}1196,8 \\
\pm \\
86,8\end{array}$ & $\begin{array}{l}1,58 ; 1,63 \\
1,59 ; 1,62 \\
1,58 ; 1,61 \\
1,60 ; 1,59\end{array}$ & $\begin{array}{l}1,60 \\
\pm \\
0,02\end{array}$ & $\begin{array}{l}778,54 ; 776,56 \\
816,48 ; 706,48 \\
714,93 ; 786,15 \\
650,00 ; 755,41\end{array}$ & $\begin{array}{c}748,0 \\
\pm \\
53,9\end{array}$ \\
\hline $\begin{array}{c}\text { T300 } \\
\text { GR600 }\end{array}$ & $\begin{array}{l}4,2 \\
2,1\end{array}$ & $\begin{array}{l}67 \\
33\end{array}$ & $\begin{array}{l}1130,1 ; 1140,0 \\
1180,0 ; 1023,3 \\
1060,0 ; 1120,1 \\
1110,2 ; 1063,0\end{array}$ & $\begin{array}{c}1103,2 \\
\pm \\
51,0\end{array}$ & $\begin{array}{l}1,73 ; 1,71 \\
1,79 ; 1,73 \\
1,78 ; 1,73 \\
1,73 ; 1,75 \\
\end{array}$ & $\begin{array}{l}1,74 \\
\pm \\
0,03\end{array}$ & $\begin{array}{l}653,23 ; 666,66 \\
659,27 ; 591,50 \\
595,50 ; 647,45 \\
641,47 ; 607,43 \\
\end{array}$ & $\begin{array}{c}632,8 \\
\pm \\
30,0\end{array}$ \\
\hline $\begin{array}{c}\text { T300 } \\
\text { GR600 }\end{array}$ & $\begin{array}{l}3,15 \\
3,15\end{array}$ & $\begin{array}{l}50 \\
50\end{array}$ & $\begin{array}{r}983,1 ; 928,5 \\
944,2 ; 869,5 \\
1018,7 ; 953,6 \\
938,1 ; 958,1 \\
\end{array}$ & $\begin{array}{c}914,9 \\
\pm \\
45,9\end{array}$ & $\begin{array}{l}1,82 ; 1,78 \\
1,79 ; 1,77 \\
1,83 ; 1,81 \\
1,81 ; 1,81 \\
\end{array}$ & $\begin{array}{c}1,80 \\
\pm \\
0,02\end{array}$ & $\begin{array}{l}540,16 ; 521,63 \\
527,48 ; 491,24 \\
556,66 ; 526,85 \\
518,28 ; 529,37\end{array}$ & $\begin{array}{c}526,5 \\
\pm \\
28,5\end{array}$ \\
\hline $\begin{array}{c}\text { T300 } \\
\text { GR600 }\end{array}$ & $\begin{array}{l}2,1 \\
4,2\end{array}$ & $\begin{array}{l}33 \\
67\end{array}$ & $\begin{array}{l}909,8 ; 906,5 \\
860,0 ; 919,5 \\
867,0 ; 903,7 \\
881,5 ; 837,5\end{array}$ & $\begin{array}{c}885,7 \\
\pm \\
28,8\end{array}$ & $\begin{array}{l}1,90 ; 1,93 \\
1,90 ; 1,89 \\
1,90 ; 1,83 \\
1,90 ; 1,94\end{array}$ & $\begin{array}{l}1,90 \\
\pm \\
0,03\end{array}$ & $\begin{array}{l}478,84 ; 469,69 \\
452,36 ; 486,51 \\
456,31 ; 493,82 \\
463,94 ; 431,70 \\
\end{array}$ & $\begin{array}{l}466,7 \\
\pm \\
20,1\end{array}$ \\
\hline
\end{tabular}


Experimental data for hybrid NOL rings mark (T300/GR600+T300)-L20 are presented in Table 4.

Table 4. Experimental data for hybrid NOL rings mark (T300/GR600+T300)-L20

\begin{tabular}{|c|c|c|c|c|c|c|c|c|}
\hline \multirow{2}{*}{$\begin{array}{c}\text { Fiber } \\
\text { designation }\end{array}$} & \multirow{2}{*}{$\begin{array}{l}\text { Layers } \\
\text { thickness } \\
(\mathrm{mm})\end{array}$} & \multirow{2}{*}{$\begin{array}{l}\text { Volume } \\
\text { content } \\
(\%)\end{array}$} & \multicolumn{2}{|c|}{ Tensile strength $(\mathrm{MPa})$} & \multicolumn{2}{|c|}{ Density $\left(\mathrm{g} / \mathrm{cm}^{3}\right)$} & \multicolumn{2}{|c|}{ Specific tensile strength $\left(\mathrm{kPam}^{3} / \mathrm{kg}\right)$} \\
\hline & & & $\mathrm{X}_{\mathrm{i}}$ & $(\bar{X} \pm \sigma)$ & $X_{i}$ & $(\bar{X} \pm \sigma)$ & $\mathrm{X}_{\mathrm{i}}$ & $(\bar{X} \pm \sigma)$ \\
\hline $\begin{array}{c}\text { T300 } \\
\text { GR600 }\end{array}$ & $\begin{array}{c}6,3 \\
0\end{array}$ & $\begin{array}{c}100 \\
0\end{array}$ & $\begin{array}{l}1277,8 ; 1304,1 \\
1335,8 ; 1182,1 \\
1156,8 ; 1276,2 \\
1180,0 ; 1225,1\end{array}$ & $\begin{array}{c}1242,2 \\
\pm \\
65,5\end{array}$ & $\begin{array}{l}1,58 ; 1,63 \\
1,59 ; 1,62 \\
1,58 ; 1,61 \\
1,60 ; 1,59\end{array}$ & $\begin{array}{l}1,60 \\
\pm \\
0,02\end{array}$ & $\begin{array}{l}808,73 ; 800,06 \\
840,12 ; 729,69 \\
732,15 ; 792,67 \\
737,50 ; 770,50\end{array}$ & $\begin{array}{c}776,4 \\
\pm \\
43,9\end{array}$ \\
\hline $\begin{array}{c}\text { T300 } \\
\text { GR600 }\end{array}$ & $\begin{array}{l}4,2 \\
2,1\end{array}$ & $\begin{array}{l}67 \\
33\end{array}$ & $\begin{array}{l}1180,1 ; 1190,3 \\
1230,1 ; 1073,3 \\
1110,2 ; 1170,3 \\
1160,8 ; 1113,2 \\
\end{array}$ & $\begin{array}{c}1153,2 \\
\pm \\
50,1\end{array}$ & $\begin{array}{l}1,70 ; 1,72 \\
1,71 ; 1,68 \\
1,68 ; 1,72 \\
1,70 ; 1,71 \\
\end{array}$ & $\begin{array}{l}1,70 \\
\pm \\
0,02\end{array}$ & $\begin{array}{l}694,17 ; 692,03 \\
719,35 ; 638,87 \\
660,83 ; 680,41 \\
682,82 ; 650,99 \\
\end{array}$ & $\begin{array}{c}677,4 \\
\pm \\
25,0\end{array}$ \\
\hline $\begin{array}{c}\text { T300 } \\
\text { GR600 }\end{array}$ & $\begin{array}{l}3,15 \\
3,15\end{array}$ & $\begin{array}{l}50 \\
50\end{array}$ & $\begin{array}{r}1050,1 ; 1060,2 \\
1100,1 ; 943,2 \\
960,2 ; 1043,3 \\
1030,2 ; 983,1 \\
\end{array}$ & $\begin{array}{c}1020,9 \\
\pm \\
53,8\end{array}$ & $\begin{array}{l}1,78 ; 1,82 \\
1,75 ; 1,83 \\
1,78 ; 1,79 \\
1,81 ; 1,79 \\
\end{array}$ & $\begin{array}{l}1,79 \\
\pm \\
0,03\end{array}$ & $\begin{array}{l}589,94 ; 582,52 \\
628,62 ; 515,41 \\
539,43 ; 582,85 \\
569,17 ; 549,28 \\
\end{array}$ & $\begin{array}{c}569,6 \\
\pm \\
36,6\end{array}$ \\
\hline $\begin{array}{c}\text { T300 } \\
\text { GR600 }\end{array}$ & $\begin{array}{l}2,1 \\
4,2\end{array}$ & $\begin{array}{l}33 \\
67\end{array}$ & $\begin{array}{c}928,3 ; 1002,6 \\
911,8 ; 911,3 \\
1018,4 ; 935,9 \\
974,4 ; 913,6\end{array}$ & $\begin{array}{c}950,0 \\
\pm \\
42,9\end{array}$ & $\begin{array}{l}1,90 ; 1,93 \\
1,90 ; 1,89 \\
1,90 ; 1,83 \\
1,90 ; 1,94\end{array}$ & $\begin{array}{l}1,90 \\
\pm \\
0,03\end{array}$ & $\begin{array}{l}488,58 ; 519,48 \\
479,89 ; 482,17 \\
536,00 ; 511,42 \\
512,84 ; 470,92\end{array}$ & $\begin{array}{l}500,1 \\
\pm \\
21,2\end{array}$ \\
\hline
\end{tabular}

In Table 5 there are experimental data for hybrid NOL rings mark (T800/GR600+T800)-0164.

Table 5. Experimental data for hybrid NOL rings mark (T800/GR600+T800)-0164

\begin{tabular}{|c|c|c|c|c|c|c|c|c|}
\hline \multirow{2}{*}{$\begin{array}{c}\text { Fiber } \\
\text { designation }\end{array}$} & \multirow{2}{*}{$\begin{array}{c}\text { Layers } \\
\text { thickness } \\
(\mathrm{mm})\end{array}$} & \multirow{2}{*}{$\begin{array}{c}\text { Volume } \\
\text { content } \\
(\%)\end{array}$} & \multicolumn{2}{|c|}{ Tensile strength (MPa) } & \multicolumn{2}{|c|}{ Density $\left(\mathrm{g} / \mathrm{cm}^{3}\right)$} & \multicolumn{2}{|c|}{ Specific tensile strength $\left(\mathrm{kPa} \mathrm{m}^{3} / \mathrm{kg}\right)$} \\
\hline & & & $\mathrm{X}_{\mathrm{i}}$ & $(\bar{X} \pm \sigma)$ & $\mathrm{X}_{\mathrm{i}}$ & $(\bar{X} \pm \sigma)$ & $\mathrm{X}_{\mathrm{i}}$ & $(\bar{X} \pm \sigma)$ \\
\hline $\begin{array}{c}\text { T800 } \\
\text { GR600 }\end{array}$ & $\begin{array}{c}6,3 \\
0\end{array}$ & $\begin{array}{c}100 \\
0\end{array}$ & $\begin{array}{l}1475,1 ; 1401,2 \\
1382,2 ; 1375,5 \\
1417,8 ; 1391,1 \\
1462,3 ; 1423,3\end{array}$ & $\begin{array}{c}1425,5 \\
\pm \\
35,7\end{array}$ & $\begin{array}{l}1,59 ; 1,63 \\
1,62 ; 1,64 \\
1,60 ; 1,62 \\
1,63 ; 1,63\end{array}$ & $\begin{array}{c}1,62 \\
\pm \\
0,02\end{array}$ & $\begin{array}{l}925,47 ; 859,63 \\
853,21 ; 838,72 \\
886,12 ; 858,70 \\
897,11 ; 873,19\end{array}$ & $\begin{array}{c}874,0 \\
\pm \\
27,9\end{array}$ \\
\hline $\begin{array}{c}\text { T800 } \\
\text { GR600 }\end{array}$ & $\begin{array}{l}4,2 \\
2,1\end{array}$ & $\begin{array}{l}67 \\
33\end{array}$ & $\begin{array}{l}1237,5 ; 1218,0 \\
1139,9 ; 1127,5 \\
1236,3 ; 1188,4 \\
1270,0 ; 1227,5 \\
\end{array}$ & $\begin{array}{c}1205,3 \\
\pm \\
50,5 \\
\end{array}$ & $\begin{array}{l}1,74 ; 1,71 \\
1,78 ; 1,78 \\
1,77 ; 1,77 \\
1,75 ; 1,72 \\
\end{array}$ & $\begin{array}{c}1,75 \\
\pm \\
0,03 \\
\end{array}$ & $\begin{array}{l}711,21 ; 712,28 \\
638,71 ; 633,43 \\
698,47 ; 671,41 \\
725,71 ; 713,66 \\
\end{array}$ & $\begin{array}{c}688,1 \\
\pm \\
35,9\end{array}$ \\
\hline $\begin{array}{c}\text { T800 } \\
\text { GR600 }\end{array}$ & $\begin{array}{l}3,15 \\
3,15\end{array}$ & $\begin{array}{l}50 \\
50\end{array}$ & $\begin{array}{l}1082,5 ; 990,0 \\
1033,0 ; 968,2 \\
1009,7 ; 981,6 \\
1022,1 ; 1020,0\end{array}$ & $\begin{array}{c}1013,4 \\
\pm \\
33,3 \\
\end{array}$ & $\begin{array}{l}1,79 ; 1,83 \\
1,78 ; 1,82 \\
1,83 ; 1,80 \\
1,81 ; 1,82 \\
\end{array}$ & $\begin{array}{c}1,81 \\
\pm \\
0,02 \\
\end{array}$ & $\begin{array}{l}604,74 ; 540,98 \\
580,33 ; 531,98 \\
551,74 ; 545,33 \\
564,69 ; 560,43 \\
\end{array}$ & $\begin{array}{c}560,0 \\
\pm \\
23,5 \\
\end{array}$ \\
\hline $\begin{array}{c}\text { T800 } \\
\text { GR600 }\end{array}$ & $\begin{array}{l}2,1 \\
4,2\end{array}$ & $\begin{array}{l}33 \\
67\end{array}$ & $\begin{array}{l}872,9 ; 923,6 \\
925,6 ; 918,7 \\
923,7 ; 935,0 \\
958,5 ; 972,2\end{array}$ & $\begin{array}{c}928,8 \\
\pm \\
29,5\end{array}$ & $\begin{array}{l}1,91 ; 1,89 \\
1,94 ; 1,94 \\
1,90 ; 1,90 \\
1,92 ; 1,95\end{array}$ & $\begin{array}{c}1,92 \\
\pm \\
0,02 \\
\end{array}$ & $\begin{array}{l}457,01 ; 488,67 \\
477,11 ; 473,55 \\
486,15 ; 492,10 \\
499,22 ; 498,56\end{array}$ & $\begin{array}{c}484,1 \\
\pm \\
20,1\end{array}$ \\
\hline $\begin{array}{c}\text { T800 } \\
\text { GR600 }\end{array}$ & $\begin{array}{c}0 \\
6,3\end{array}$ & $\begin{array}{c}0 \\
100\end{array}$ & $\begin{array}{c}840,1 ; 885,5 \\
815,5 ; 881,4803,3 \\
856,9 \\
821,4 ; 787,4\end{array}$ & $\begin{array}{c}836,4 \\
\pm \\
35,5\end{array}$ & $\begin{array}{l}2,01 ; 2,04 \\
2,00 ; 2,04 \\
2,01 ; 2,01 \\
2,00 ; 1,99 \\
\end{array}$ & $\begin{array}{c}2,01 \\
\pm \\
0,02\end{array}$ & $\begin{array}{l}417,96 ; 434,07 \\
432,06 ; 399,65 \\
426,32 ; 410,70 \\
407,75 ; 395,73 \\
\end{array}$ & $\begin{array}{c}415,5 \\
\pm \\
14,5\end{array}$ \\
\hline
\end{tabular}

Experimental data for hybrid NOL rings mark (T800/GR600+T800)-L20 are quoted in Table 6

Table 6. Experimental data for hybrid NOL rings mark (T800/GR600+T800)-L20

\begin{tabular}{|c|c|c|c|c|c|c|c|c|}
\hline \multirow{2}{*}{$\begin{array}{c}\text { Fiber } \\
\text { designation }\end{array}$} & \multirow{2}{*}{$\begin{array}{l}\text { Layers } \\
\text { thickness } \\
(\mathrm{mm})\end{array}$} & \multirow{2}{*}{$\begin{array}{c}\text { Volume } \\
\text { content } \\
(\%)\end{array}$} & \multicolumn{2}{|c|}{ Tensile strength (MPa) } & \multicolumn{2}{|c|}{ Density $\left(\mathrm{g} / \mathrm{cm}^{3}\right)$} & \multicolumn{2}{|c|}{ Specific tensile strength $\left(\mathrm{kPa} \mathrm{m}^{3} / \mathrm{kg}\right)$} \\
\hline & & & $X_{i}$ & $(\bar{X} \pm \sigma)$ & $\mathrm{X}_{\mathrm{i}}$ & $(\bar{X} \pm \sigma)$ & $\mathrm{X}_{\mathrm{i}}$ & $(\bar{X} \pm \sigma)$ \\
\hline $\begin{array}{c}\text { T800 } \\
\text { GR600 }\end{array}$ & $\begin{array}{c}6,3 \\
0\end{array}$ & $\begin{array}{c}100 \\
0\end{array}$ & $\begin{array}{l}1485,1 ; 1437,2 \\
1407,2 ; 1398,1 \\
1451,1 ; 1415,3 \\
1498,2 ; 1452,0\end{array}$ & $\begin{array}{c}1443,1 \\
\pm \\
36,0\end{array}$ & $\begin{array}{l}1,60 ; 1,67 \\
1,34 ; 1,64 \\
1,66 ; 1,61 \\
1,62 ; 1,61\end{array}$ & $\begin{array}{l}1,63 \\
\pm \\
0,03\end{array}$ & $\begin{array}{l}928,18 ; 860,59 \\
858,05 ; 852,50 \\
874,15 ; 879,07 \\
924,81 ; 901,86\end{array}$ & $\begin{array}{c}884,9 \\
\pm \\
29,9\end{array}$ \\
\hline $\begin{array}{c}\text { T800 } \\
\text { GR600 }\end{array}$ & $\begin{array}{l}4,2 \\
2,1\end{array}$ & $\begin{array}{l}67 \\
33\end{array}$ & $\begin{array}{l}1291,6 ; 1084,4 \\
1280,8 ; 1276,4 \\
1204,2 ; 1236,8 \\
1243,2 ; 1179,2\end{array}$ & $\begin{array}{c}1224,6 \\
\pm \\
68,6\end{array}$ & $\begin{array}{l}1,75 ; 1,74 \\
1,71 ; 1,75 \\
1,74 ; 1,76 \\
1,72 ; 1,76\end{array}$ & $\begin{array}{l}1,74 \\
\pm \\
0,02\end{array}$ & $\begin{array}{l}738,05 ; 623,22 \\
749,00 ; 729,37 \\
629,07 ; 702,72 \\
722,79 ; 670,00\end{array}$ & $\begin{array}{l}703,4 \\
\pm \\
41,4\end{array}$ \\
\hline $\begin{array}{c}\text { T800 } \\
\text { GR600 }\end{array}$ & $\begin{array}{l}3,15 \\
3,15\end{array}$ & $\begin{array}{l}50 \\
50\end{array}$ & $\begin{array}{l}1067,9 ; 1100,0 \\
1078,6 ; 1032,1 \\
1055,1 ; 981,1 \\
1113,6 ; 1025,6\end{array}$ & $\begin{array}{c}1056,7 \\
\pm \\
43,1\end{array}$ & $\begin{array}{l}1,83 ; 1,79 \\
1,84 ; 1,80 \\
1,79 ; 1,82 \\
1,81 ; 1,86\end{array}$ & $\begin{array}{l}1,82 \\
\pm \\
0,02\end{array}$ & $\begin{array}{l}583,55 ; 614,52 \\
586,19 ; 573,39 \\
589,44 ; 539,07 \\
615,25 ; 551,39\end{array}$ & $\begin{array}{c}581,6 \\
\pm \\
30,0\end{array}$ \\
\hline $\begin{array}{c}\text { T800 } \\
\text { GR600 }\end{array}$ & $\begin{array}{l}2,1 \\
4,2\end{array}$ & $\begin{array}{l}33 \\
67\end{array}$ & $\begin{array}{c}924,1 ; 1001,2 \\
1002,4 ; 1067,5 \\
983,2 ; 981,1 \\
930,0 ; 935,2\end{array}$ & $\begin{array}{l}978,0 \\
\pm \\
48,1\end{array}$ & $\begin{array}{l}1,95 ; 1,96 \\
1,94 ; 1,94 \\
1,89 ; 1,91 \\
1,88 ; 1,91\end{array}$ & $\begin{array}{l}1,92 \\
\pm \\
0,03\end{array}$ & $\begin{array}{l}473,89 ; 510,81 \\
516,70 ; 550,25 \\
520,21 ; 513,66 \\
494,68 ; 489,63\end{array}$ & $\begin{array}{c}508,7 \\
\pm \\
23,1\end{array}$ \\
\hline
\end{tabular}


Arithmetic mean values for tensile strength, density and specific tensile strength are based on 8 single values, as can be seen in Tables 1-6. In the mentioned tables it can be seen that almost all single values for tensile strength, density and specific tensile strength are equalized because only in a few cases standard deviations are higher than $5 \%$ of arithmetic mean values.

Dependence of tensile strength of hybrid NOL rings marks $($ K49/GR600 + K49), (T300/GR600 + T300) and (T800/GR600 + T800), all impregnated with epoxy resin 0164, versus volume content of glass roving GR600 is presented in Fig.3.

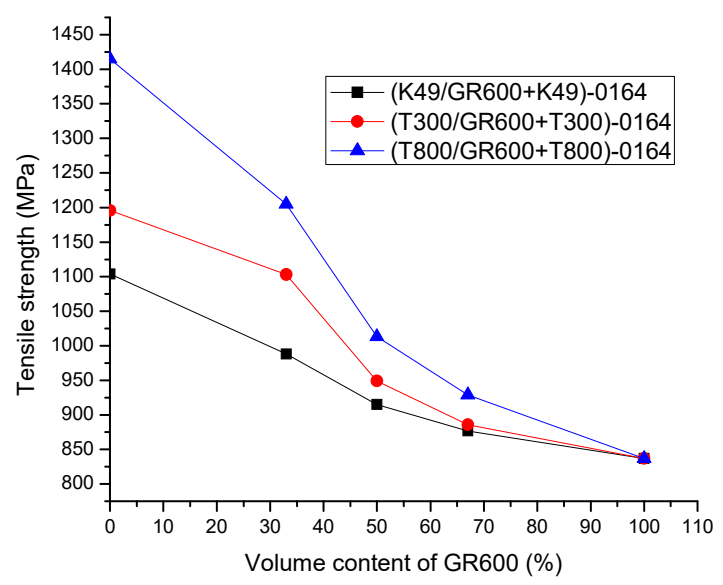

Figure 3. Dependence of tensile strength of hybrid NOL rings marks (K49/GR600+K49), (T300/GR600+T300) and (T800/GR600+T800), all impregnated with epoxy resin 0164 , versus volume content of glass roving GR600.

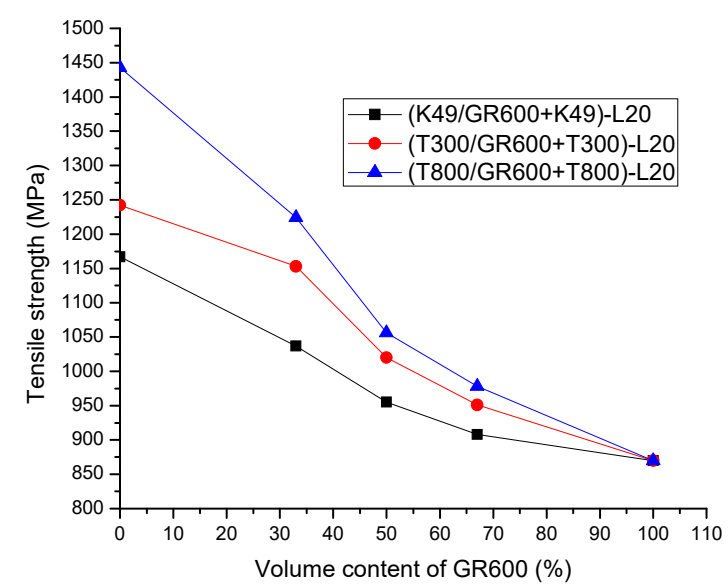

Figure 4. Dependence of tensile strength versus volume content of glass fiber GR 600 for hybrid NOL rings marks (K49/GR600+K49), (T300/GR600+T300) and (T800/GR600+T800), all impregnated with epoxy resin L20.

Fig.4 shows dependence of tensile strength versus volume content of glass fiber GR 600 for hybrid NOL rings marks $(\mathrm{K} 49 / \mathrm{GR} 600+\mathrm{K} 49),(\mathrm{T} 300 / \mathrm{GR} 600+\mathrm{T} 300)$ and (T800/GR600 + T800), all impregnated with epoxy resin L20.

From Figures 3 and 4 it is clearly visible that hybrid NOL rings mark (T300/GR600+T300) and (T800/GR600+T800) containing $67 \%$ vol of carbon fiber T300 and carbon fiber T800, respectively, have a hasty growth of tensile strength. Hybrid NOL ring mark (K49/GR600+K49) containing $67 \%$ vol aramide fiber $\mathrm{K} 49$ has an increase of the mentioned property but it is not so high. Hybrid NOL ring mark (T800/GR600+T800), impregnated with epoxy resin system L20 has the highest tensile strength value of all tested hybrid specimens.
Dependence of density of volume content of glass roving GR600 at hybrid NOL rings marks (K49/GR600 + K49), $(\mathrm{T} 300 / \mathrm{GR} 600+\mathrm{T} 300)$ and (T800/GR600 + T800), all impregnated with epoxy resin system 0164, is presented in Fig.5.

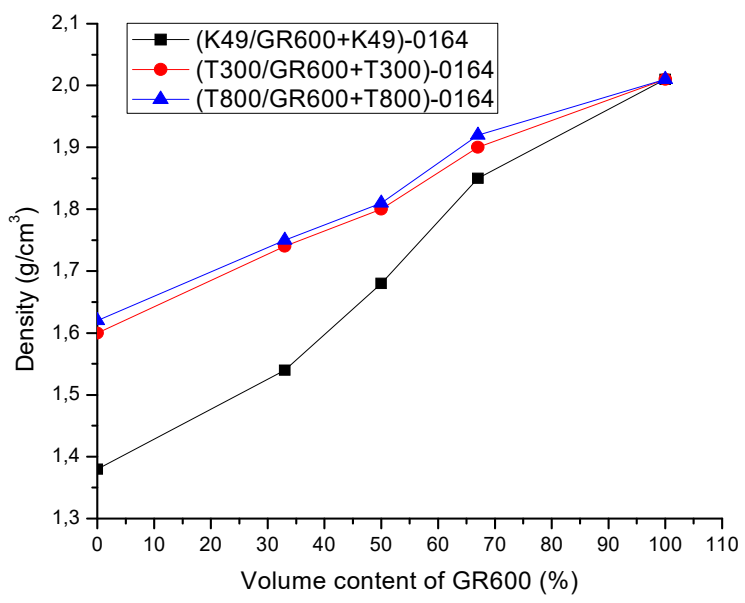

Figure 5. Dependence of density of volume content of glass roving GR600 at hybrid NOL rings marks (K49/GR600+K49), (T300/GR600+T300) and (T800/GR600+T800), all impregnated with epoxy resin system 0164 .

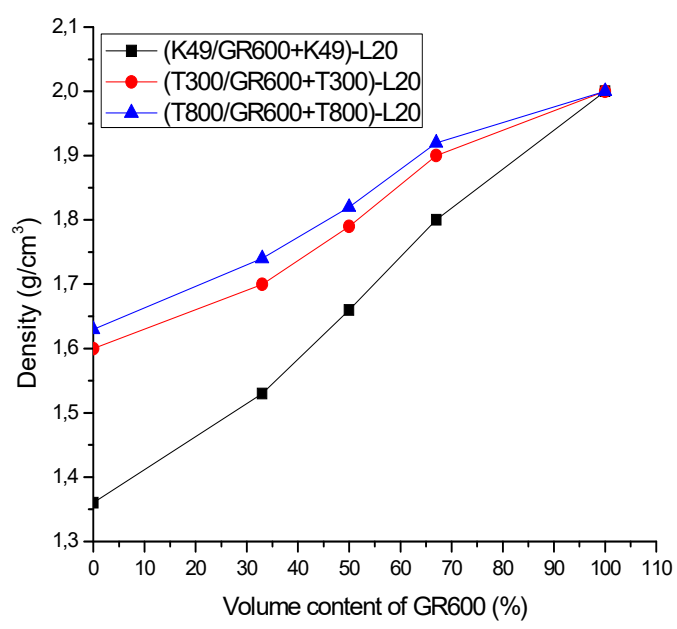

Figure 6. Correlations between density and volume content of glass roving GR600 at hybrid NOL rings marks (K49/GR600+K49), (T300/GR600+T300) and (T800/GR600+T800), all impregnated with epoxy resin L20.

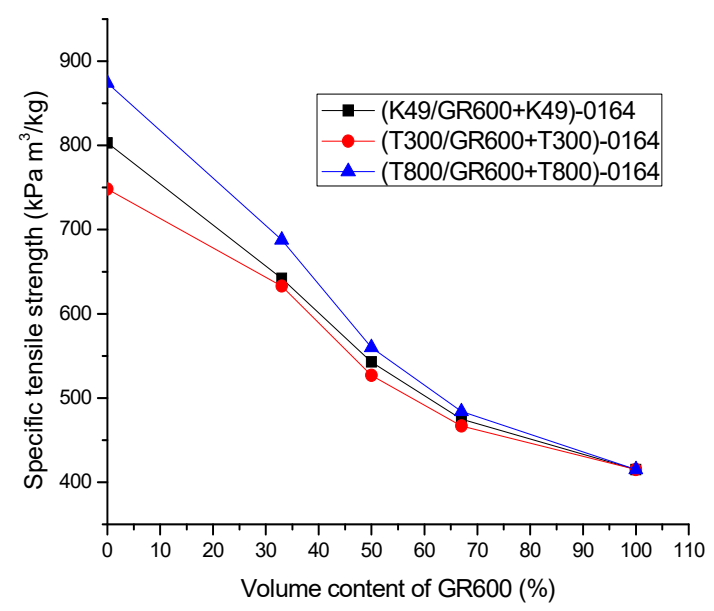

Figure 7. Specific tensile strength of hybrid NOL rings marks (K49/GR600+K49), (T300/GR600+T300) and (T800/GR600+T800), all impregnated with epoxy resin 0164 , versus volume content of glass roving GR600. 
Correlations between density and volume content of glass roving GR600 at hybrid NOL rings marks (K49/GR600 + K49), (T300/GR600 + T300) and (T800/GR600 + T800), all impregnated with epoxy resin L20, are shown in Fig.6.

Density of NOL ring mark (K49/GR600+K49) with both epoxy resin system 0164 and L20 is meaningfully lower than densities of hybrid NOL rings marks (T300/GR600 + T300) and (T800/GR600 + T800) impregnated with the same resins systems, as can be seen in Figures 5 and 6 .

Specific tensile strength of hybrid NOL rings marks $(\mathrm{K} 49 / \mathrm{GR} 600+\mathrm{K} 49),(\mathrm{T} 300 / \mathrm{GR} 600+\mathrm{T} 300)$ and (T800/GR600 + T800), all impregnated with epoxy resin 0164, versus volume content of glass roving GR600, is presented in Fig.7.

Correlations between specific tensile strength of hybrid NOL rings marks (K49/GR600 + K49), (T300/GR600 + T300) and (T800/GR600 + T800), all impregnated with epoxy resin L20, and volume content of glass roving GR600, are shown in Fig.8.

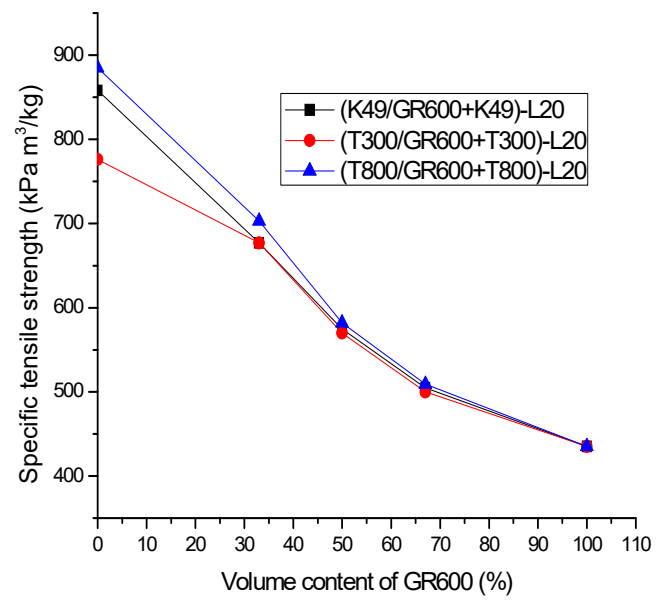

Figure 8. Correlations between specific tensile strength of hybrid NOL rings marks (K49/GR600+K49), (T300/GR600+T300) and (T800/GR600+T800), all impregnated with epoxy resin L20, and volume content of glass roving GR600.

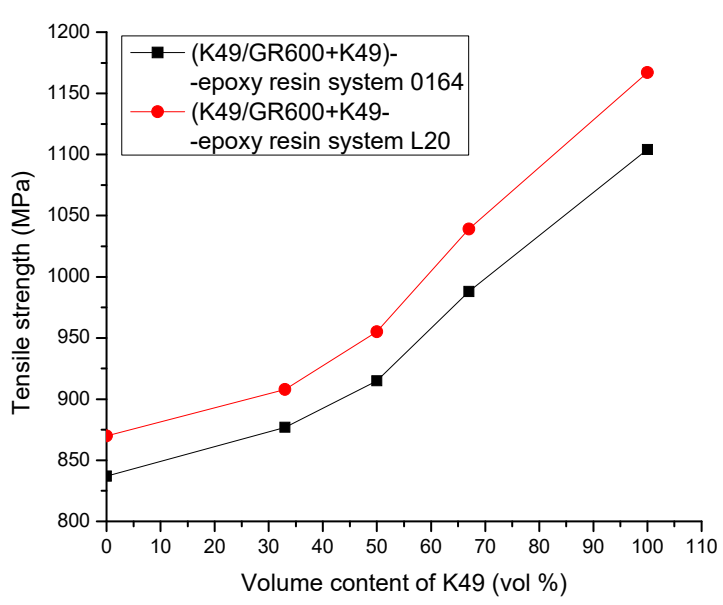

Figure 9. Dependence of tensile strength versus volume content of aramide roving K49 at hybrid NOL rings mark (K49/GR600+K49), impregnated with both epoxy resin systems 0164 and L20.

Based on data presented in Figures 7 and 8 one can conclude that all three NOL rings have a similar trend of increasing of specific tensile strength, but NOL ring mark $(\mathrm{T} 800 / \mathrm{GR} 600+\mathrm{T} 800)$ has the highest value of this characteristic.

From many points of view, it is important to establish the influence of epoxy resin systems used for a production of hybrid NOL rings. Dependence of tensile strength and specific tensile strength of hybrid NOL rings marks $($ K49/GR600 + K49), (T300/GR600 + T300) and (T800/GR600 + T800), all impregnated with epoxy resin systems 0164 and L20, versus volume content of aramide roving $\mathrm{K} 49$, carbon roving $\mathrm{T} 300$ and carbon roving $\mathrm{T} 800$, respectively, are presented in following Figures.

Dependence of tensile strength versus volume content of aramide roving K49 at hybrid NOL rings mark (K49/GR600 + K49), impregnated with both epoxy resin systems 0164 and L20, is shown in Fig.9.

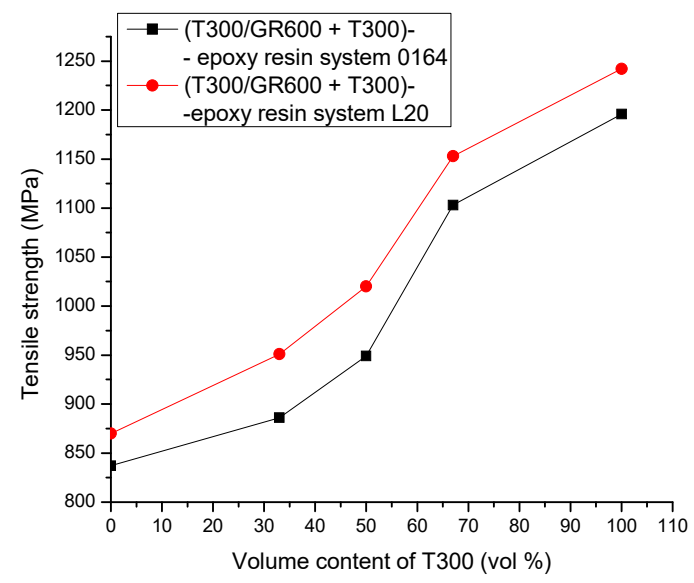

Figure 10. Tensile strength versus volume content of carbon fiber T300 at hybrid NOL rings mark (T300+GR600/T300) impregnated with both epoxy resin systems 0164 and L20.

Tensile strength versus volume content of carbon fiber T300 at hybrid NOL rings mark (T300 + GR600/T300), impregnated with both epoxy resin systems 0164 and L20 is shown in Fig.10.

Dependence of tensile strength versus volume content of carbon roving T800 at hybrid NOL rings mark (T800/GR600 + T800), impregnated with both epoxy resin systems 0164 and L20, is shown in Fig. 11.

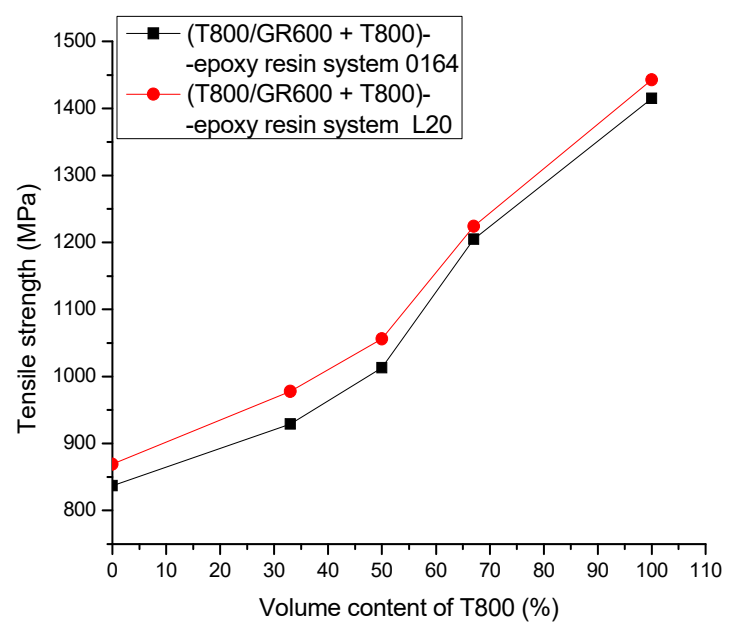

Figure 11. Dependence of tensile strength versus volume content of carbon roving T800 at hybrid NOL rings mark (T800/GR600+T800) impregnated with both epoxy resin systems 0164 and L20.

Hybrid NOL rings marks (K49/GR600 + K49), (T300/GR600 + T300) and (T800/GR600+T800) impregnated with epoxy resin system L20 have higher tensile strength values than the hybrid NOL rings of the same marks impregnated with epoxy resin system 0164, for the same volume content of appropriate fiber. This difference is visible in Figures 9, 10 and 11. 
Specific tensile strength of hybrid NOL rings mark (K49/GR600+K49), impregnated with both epoxy resin systems 0164 and L20, versus volume content of aramide roving K49, is presented in Fig. 12.

Specific tensile strength of hybrid NOL rings mark (T300/GR600+T300), impregnated with both epoxy resin systems 0164 and L20, versus volume content of carbon roving T300, is presented in Fig.13.

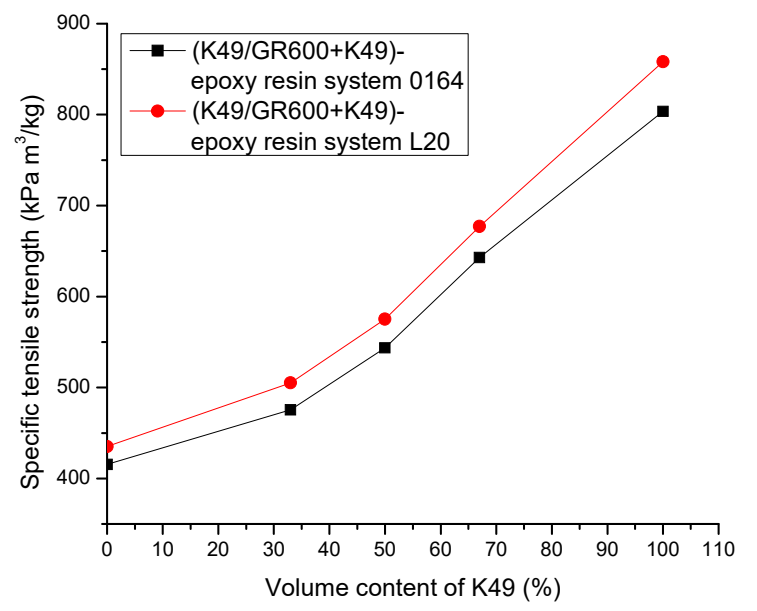

Figure 12. Specific tensile strength of hybrid NOL rings mark (K49/GR600+K49), impregnated with both epoxy resin systems 0164 and L20, versus volume content of aramide roving K49.

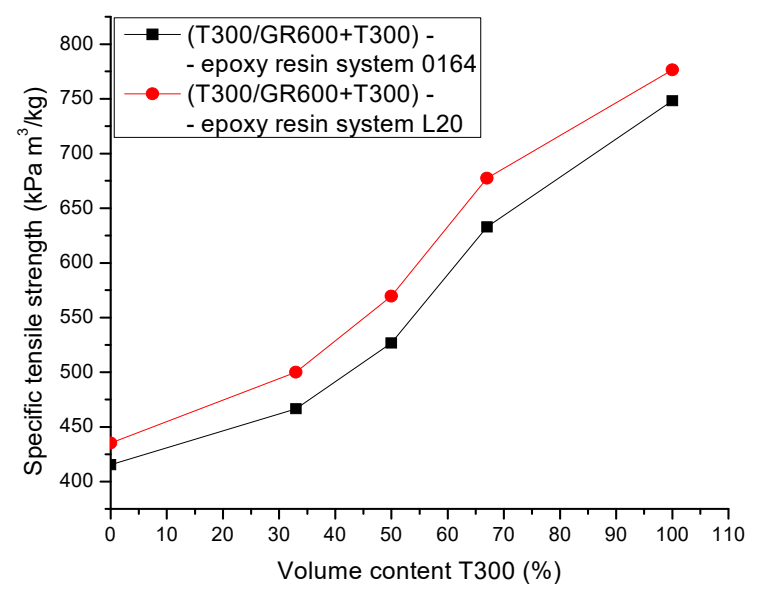

Figure 13. Specific tensile strength of hybrid NOL rings mark (T300/GR600+T300) impregnated with both epoxy resin systems 0164 and L20, versus volume content of carbon roving T300.

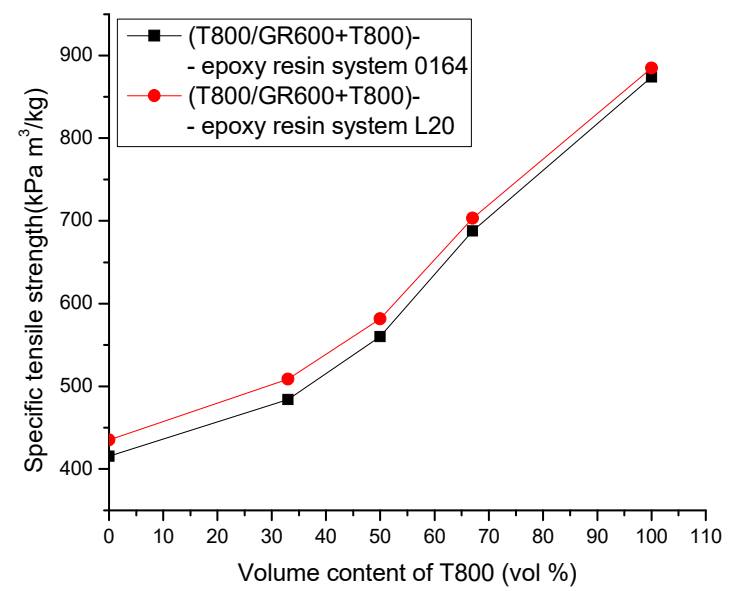

Figure 14. Correlations between specific tensile strength of hybrid NOL rings mark (T800/GR600+T800) impregnated with both epoxy resin systems 0164 and L20, and volume content of carbon roving T800.
Correlations between specific tensile strength of hybrid NOL rings mark (T800/GR600 + T800) impregnated with both epoxy resin systems 0164 and L20, and volume content of carbon roving T800, are presented in Fig. 14.

From Figures 12, 13 and 14 it is clearly seen that hybrid NOL rings marks (K49/GR600 + K49), (T300/GR600 + T300) and (T800/GR600 + T800) impregnated with epoxy resin system 0164 have lower specific tensile strength values regarding the hybrid NOL rings of the same marks impregnated with epoxy resin system L20, for the same volume content of appropriate fiber.

\section{Conclusions}

1. Hybrid composite material consisting of carbon fiber T800 (67 \% vol) and glass fiber GR600 (33 \% vol) impregnated with epoxy resin system L20 has the highest both the tensile strength value and the specific tensile strength value of all six hybride types (precisely stated 18 hybride subtypes) tested in this investigation.

2. The two lowest values of both tensile strength and the specific tensile strength have hybrid materials containing aramide fiber K49 (33 \% vol) and glass fiber GR600 (67 $\%$ vol) and epoxy resin system 0164 and hybrid NOL ring with wound carbon fiber T300 (33\% vol) and glass fiber GR600 (67 \% vol) impregnated with epoxy resin system 0164.

3. Increasing of volume content of aramide fiber K49, carbon fiber T300 and carbon fiber T800 in appropriate hybrid composites with glass fiber GR600 increase both the tensile strength value and the specific tensile strength value and decrease the density value, no matter used epoxy resin system.

4. Hybrid composites produced with epoxy resin system L20 have higher both the tensile strength values and the specific tensile strength values and lower density values than corresponding hybrid composites impregnated with epoxy resin system 0164, no matter used combinations of reinforcements.

5. Epoxy resin system L20 is more convenient to use not only for better achieved characteristics of the mentioned hybrid composite, but regarding moderate temperature curing procedure, especially if impregnated fibers are wound around heat sensitive elements.

\section{Literature}

[1] RADULOVIĆ,J.: Thin wall and Thick Wall Filament Wound Polymeric Composite Tubes: Mechanical Characteristics Caused by Internal Hydraulic Pressure, Scientific Technical Review, 2013, Vol.63, No.1, pp. 63-69, Belgrade.

[2] GROOVER,M.P.: Fundamentals of Modern Manufacturing, Materials, Processes and Systems, John Wiley and Sons Inc., Hoboken, 2010, ISBN 978-0470-467008.

[3] RADULOVIĆ,J., KARKALIĆ,R.: Filament Wound Filter HousingKey for Rational Purification Process of Highly Corrosive Solutions, Scientific Technical Review, 2019, Vol. 69, No. 1, pp. 45-52, Belgrade.

[4] https://image.slidesharecdn.com/frpmaterials-130423162733phpapp02/95/frp-materials-9-638.jpg?cb=1366734580

[5] ROSATO,D.V., ROSATO,M.G., $\quad$ ROSATO,D.V.: Concise Encyclopedia of Plastics, Kluwer Academic Publishers, Norwell, 2000, ISBN 0-7923-8496-2.

[6] ROSATO,D.V., ROSATO,D.V.: Reinforced Plastics Handbook, 3rd ed., Elsevier Advanced Technology Ltd., Oxford, 2004, ISBN 18561 74506.

[7] HARRIS,B.: Engineering Composite Materials, Institute of Materials, London, 1979.

[8] KELLY,A.: Concise Encyclopedia of Composite Materials, Pergamon 
Press, Oxford, 1988, ISBN 0-08-034718-9.

[9] MISKA,K.H.: Hybridizing - expands properties, cut costs of advanced composites, Materials Engineering, 1978, NO.8, pp. 35-37.

[10] Nguyen H., Zatar W. and Mutsuyoshi H., Mechanical properties of hybrid polymer composite in Hybrid Polymer Composite Materials, Properties and Characterization, 2017, pp. 83-113, 2017 Elsevier Ltd.

[11] MUNDRA,R.R.: Hybrid Materials, https://prezi.com/svsgpadl_hvu/hybrid-composite-materials

[12] JAWAID,M.,TARIQ,M., SABA,N.: (Ed.) Durability and Life Prediction in Biocomposites, Fiber-Reinforced Composites and Hybrid Composites, 2019, Woodhead Publishing Series in Composites Science and Engineering, ISBN 978-0-08-102290-0.

[13] ASHBY,M.F., BRÉCHET,Y.J.M.: Designing Hybrid Materials, Acta Mater., 51 (2003) 5801-5821.

[14] SUMMERSCALES,J.: Hybrid composites, https://www.slideserve.com/nevin/hybrid-composites.

[15] YAMADA,A, SASABE,H, OSADA,Y, SHIRODA,Y, YAMAMOTO,I.: Concepts of hybrid materials, hybrid materials concept and case studies. Ohio: ASM International; 1989.

[16] GÓMEZ-ROMERO,P., SANCHEZ.C.: Functional Hybrid Materials, ed. by P. Gómez-Romero and C. Sanchez, Wiley-VCH Verlag GmbH \& Co., (2004), pp. 1-6.

[17] NIIZEKI,N.: What are Hybrid Materials?, Sensor Tech., 6 [2] (1986), pp. 42-44.

[18] JAWAID,M., THARIQ,M., SABA,N.: (Ed.), Mechanical and Physical Testing of Biocomposites, Fibre-Reinforced Composites and Hybrid Composites, Woodhead Publishing Series in Composites Science and Engineering, https://doi.org/10.1016/B978-0-08-102292-4.00010-2 Copyright @ 2019 Elsevier Ltd. ISBN: 978-0-08-102292-4.

[19] PEROV,B.V., KHOROSHILOVA,I.P.: Soviet Advanced Composites Technology Series book series (SACTS, volume 4) in Polymer Matrix Composites, (ed. Shalin R. E.), pp. 269-304, (C) Chapman \& Hall 1995.

[20] MAKISIMA,A.: Possibility of Hybrids Materials, Ceramic Japan, 39, (2004), pp. 90-91.

[21] ZHANG,J., CHAISOMBAT,K., HE,S., WANG,C.H.: Hybrid Composite Laminates Reinforced With Glass / Carbon Woven Fabrics For Light Weight Load Bearing Structures, Mater. Des., vol. 36, pp. 75-80, 2012.

[22] RAGHAVALU THIRUMALAI, D.P., LøGSTRUP ANDERSEN,T., MARKUSSEN, C. M., MADSEN,B., \& LILHOLT,H.: (2013). Tensile and compression properties of hybrid composites $-A$ comparative study, In Proceedings of the 19th International Conference on
Composite Materials (ICCM19) (pp. 1029-1035). Canadian Association for Composite Structures and Materials.

[23] IRINA,M.M.W., AZMI,A.I., TAN,C.L., LEE,C.C., KHALIL,A.N.M.: Evaluation of Mechanical Properties of Hybrid Fiber Reinforced Polymer Composites and Their Architecture, 2nd International Materials, Industrial, and Manufacturing Engineering Conference, MIMEC2015, 4-6 February 2015, Bali, Indonesia.

[24] ZURAIDA,A., KHALID,A.A., ISMAIL,A.F.: Performance of hybrid filament wound composite tubes subjected to quasi static indentation, Materials \& Design, Volume 28, Issue 1, 2007, Pages 71-77, 2005 Elsevier Ltd.

[25] ÖZKAN ÖZBEK: Determination Of Mechanical Behaviors Of Filament Wound Hybrid Composite Pipes, Thesis, Graduate School Of Natural \& Applied Sciences, Gaziantep University, Republic Of Turkey, September 2019.

[26] TARIQ,M., NISAR,S., SHAH,A., SOHAIB,A.: Effect of Hybrid Reinforcement on the Performance of Filament Wound Hollow Shaft, Composite Structures, Volume 184, October 2017, DOI: 10.1016/j.compstruct.2017.09.098.

[27] RADULOVIĆ,J., ČITAKOVIĆ,S.: Mechanical Characteristics of Joints Between Glass Fiber Reinforced Composite Tubes and Steel Cylinder Obtained by Different Fastening Elements, Scientific Technical Review, 2016,Vol.66, No.2, pp.28-35,UDK: 539.42:621.791.05:623.466.3, COSATI: 11-04, 07-04, Belgrade.

[28] RICHARDSON,T.: Composites- $a$ design guide, Industrial Press Inc.,200 Madison Avenue, New York, 1987.

[29] RADULOVIĆ,J.: Filament Wound Composite Plastic Tubes: Relationship between Winding Structures and their Hydraulic and Mechanical Properties, Scientific Technical Review, 2011, Vol.61, No.3-4, pp. 73-77, Belgrade.

[30] RADULOVIĆ,J.: Influence of Internal Cyclic Pressure on Filamentwound Composite Tube Quality, Scientific Technical Review, 2010, Vol LX, No 1, pp. 54-60, Belgrade.

[31] ASTM D2290-16, Standard Test Method for Apparent Hoop Tensile Strength of Plastic or Reinforced Plastic Pipe, ASTM International, West Conshohocken, PA, 2016.

[32] SRPS EN ISO 1183-1 Plastics-Methods for determining the density of non-cellular plastics-Part 1: Immersion method, liquid pyknometer method and titration method, Institute for Standardization of Serbia, Belgrade, 2013.

\title{
Hibridni mokronamotani materijali: Zatezne karakteristike kompozita (aramidno vlakno/stakleno vlakno)-epoksi smola i kompozita (ugljenično vlakno/stakleno vlakno)-epoksi smola
}

\begin{abstract}
U ovom radu prikazane su zatezne karakteristike mokronamotanog hibridnog kompozita stakleno ;lakno-aramidno vlakno/epoksi smola i hibridnog kompozita stakleno vlakno-dva ugljenična vlakna/epoksi smola.

Osnovni pojmovi o hibridnim kompozitnim materijalima (poreklo, razlozi izrade, prednosti, definicije, nivoi hibridizacije, načini klasifikacije, tipovi, kategorizacija, moguće interakcije između konstituenata) i korišćenim ojačivačima i matricama su opisani.

Za izradu NOL prstenova korišćena su četiri ojačivača (stakleno vlakno, aromatsko poliamidno vlakno i dva ugljenična vlakna) i dve matrice (epoksi sistem visoke i umerene temperature očvršćavanja).

Na osnovu eksperimentalno dobijenih rezultata zaključeno je da hibridni kompozitni materijal koji se sastoji od ugljeničnog vlakna T800 (67 zapreminskih \%) i staklenog vlakna GR600 (33 zapreminskih \%) impregnisanih sistemom epoksi smole L20 ima najveću vrednosti i zatezne čvrstoće i specifične zatezne čvrstoće. Dve najniže vrednosti i zatezne čvrstoće i specifične zatezne čvrstoće imaju hibridni kompozitni materijal koji sadrži aramidno vlakno K49 (33 zapreminskih \%) i stakleno vlakno GR600 (67 zapreminskih \%) impregnisanih sistemom epoksi smole 0164 i hibridni NOL prsten namotan sa ugljeničnim vlaknom T300 (33 zapreminskih \%) i staklenim vlaknom GR600 (67 zapreminskih \%) impregnisanih istim sistemom epoksi smole.

Ova istraživanja su istakla da povećanje zapreminskog sadržaja aramidnog vlakna K49, ugljeničnog vlakna T300 i ugljeničnog vlakna T800 u odgovarajućim hibridnim kompozitima sa staklenim vlaknom GR600 povećava vrednosti $i$ zatezne čvrstoće i specifične zatezne čvrstoće i smanjuje vrednosti gustine, bez obzira na korišćen sistem epoksi smole.
\end{abstract}

